\title{
Analisis Dinamik Model Transmisi COVID-19 dengan Melibatkan Intervensi Karantina
}

\author{
Resmawan $^{1 *}$, Agusyarif Rezka Nuha², Lailany Yahya ${ }^{3}$ \\ 1,2,3 Jurusan Matematika, Fakultas MIPA, Universitas Negeri Gorontalo, \\ Jl. Prof. Dr. Ing. B. J. Habibie, Tilongkabila, Kabupaten Bone Bolango 96119, Gorontalo, Indonesia \\ *Penulis Korespondensi.Email: resmawan@ung.ac.id
}

\begin{abstract}
ABSTRAK
Makalah ini membahas dinamika transmisi COVID-19 dengan melibatkan intervensi karantina. Model dikonstruksi dengan melibatkan tiga kelas penyebab infeksi, yaitu kelas manusia terpapar, kelas manusia terinfeksi tanpa gejala klinis, dan kelas manusia terinfeksi disertai gejala klinis. Variabel yang merepresentasikan intervensi karantina untuk menekan pertumbuhan infeksi juga dipertimbangkan pada model. Selanjutnya, analisis model difokuskan pada eksistensi titik kesetimbangan dan simulasi numerik untuk menunjukkan dinamika populasi secara visual. Model yang dikonstruksi membentuk model SEAQIR yang memiliki dua titik kesetimbangan, yaitu titik kesetimbangan bebas penyakit dan titik kesetimbangan endemik. Analisis kestabilan menunjukkan bahwa titik kesetimbangan bebas penyakit bersifat stabil asimtotik lokal pada saat $R_{0}<1$ dan tidak stabil pada saat $R_{0}>1$. Simulasi numerik menunjukkan bahwa peningkatan intervensi berupa karantina dapat berkontribusi memperlambat transmisi COVID-19 sehingga diharapkan dapat mencegah terjadinya wabah pada populasi.
\end{abstract}

Kata Kunci:

Analisis Dinamik; Transmisi COVID-19; Titik kesetimbangan; Karantina

ABSTRACT

This paper discusses the dynamics of COVID-19 transmission by involving quarantine interventions. The model was constructed by involving three classes of infectious causes, namely the exposed human class, asymptotically infected human class, and symptomatic infected human class. Variables were representing quarantine interventions to suppress infection growth were also considered in the model. Furthermore, model analysis is focused on the existence of equilibrium points and numerical simulations to visually showed population dynamics. The constructed model forms the SEAQIR model which has two equilibrium points, namely a disease-free equilibrium point and an endemic equilibrium point. The stability analysis showed that the disease-free equilibrium point was locally asymptotically stable at $R_{0}<1$ and unstable at $R_{0}>1$. Numerical simulations showed that increasing interventions in the form of quarantine could contribute to slowing the transmission of COVID-19 so that it is hoped that it can prevent outbreaks in the population.

Keywords:

Dynamic Analysis; COVID-19 Transmission; Equilibrium Point; Quarantine

Format Sitasi:

R. Resmawan, A.R. Nuha and L. Yahya, "Analisis Dinamik Model Transmisi COVID-19 dengan Melibatkan Intervensi Karantina," Jambura J. Math., vol. 3, no. 1, pp. 66-79, 2021

e-ISSN: 2656-1344 @ 2021 R. Resmawan, A.R. Nuha, L. Yahya | Under the licence CC BY-NC 4.0

Received: 16 December 2020 | Accepted: 28 December 2020 | Online: 2 January 2021 


\section{Pendahuluan}

Coronavirus Disease adalah penyakit menular yang disebabkan oleh jenis virus corona yang baru ditemukan di Wuhan, Provinsi Hubei, China pada Desember 2019 [1]. Penelitian telah menunjukkan bahwa penyakit ini disebabkan oleh sindrom pernapasan akut parahcoronavirus 2 (SARS-CoV-2) yang kemudian diberi nama Coronavirus Disease 2019 (COVID-19) oleh World Health Organization (WHO) [2][3]. Pasien dengan COVID19 memiliki gejala seperti demam, batuk kering, dan kelelahan pada tahap awal, dan kemudian dapat mengembangkan gangguan pernapasan akut (ARDS), gagal pernapasan, syok, dan beberapa organfailure, yang mungkin fatal [3][4]. Hasil penelitian menunjukkan bahwa pasien dengan gejala ringan membutuhkan waktu seminggu atau lebih untuk pulih, sementara kasus yang parah secara bertahap mengalami kegagalan pernapasan yang dapat menyebabkan kematian [5]. Tingkat penularan yang sangat tinggi menyebakan WHO menetapkan kasus ini sebagai pandemi sejak awal 2020. Bahkan penularan COVID-19 lebih tinggi dibandingkan dengan SARS-CoV, MERS-CoV dan sejauh ini telah mengakibatkan lebih dari 1 juta kematian di seluruh dunia [6]. Tingginya kasus kematian dari COVID-19 menyebabkan semua negara dan berbagai kalangan terlibat aktif untuk berkontribusi menemukan solusi yang tepat dalam penanganannya, termasuk dalam hal ini pakar-pakar pemodelan matematika dari berbagai negara. Pemodelan matematika termasuk salah satu alat utama dalam perencanaan epidemik yang dapat membantu mempermudah penyelesaian masalah COVID-19. Melalui pemodelan matematika, dapat diidentifikasi hubungan transmisi COVID-19 dengan berbagai parameter epidemiologi, yang dapat membantu dalam perencanaan dan mempertimbangkan langkah-langkah pengendalian yang tepat.

Pembahasan COVID-19 dalam sudut pandang pemodelan matematika hingga saat ini masih terus dikembangkan. Sejak awal kasus ini terjadi, berbagai model telah dikonstruksi, termasuk yang melibatkan variabel reservoir yang menandai awal mula virus menjangkiti manusia [7]-[11], model yang membahas perbandingan kasus COVID19 dengan kasus MERS yang pernah terjadi di negara-negara timur tengah dan Korea [12], dan beberapa kajian yang dilakukan untuk melakukan prediksi terhadap kasus yang akan tejadi [13][14]. Beberapa model lain yang membahas optimal kontrol dapat ditemukan pada [15]-[17]. Beberapa model sebelumnya menjelaskan bahwa proses penularan penyakit diakibatkan oleh adanya kontak dari individu terinfeksi disertai gejala klinis maupun terinfeksi tanpa gejala klinis dengan individu rentan. Sementara itu, beberapa kasus harian yang dilaporkan penularan virus dapat terjadi dari individu terpapar (masa inkubasi) ke individu rentan [18].

Pada makalah ini, diperkenalkan model matematika penyebaran COVID-19 dengan mempertimbangkan penyebab infeksi yang terdiri atas tiga subpopulasi yaitu manusia terpapar dalam masa inkubasi, manusia terinfeksi tanpa gejala klinis, dan manusia terinfeksi disertai gejala klinis. Disamping itu, variabel reservoir yang banyak digunakan pada model-model sebelumnya diabaikan. Variabel reservoir merepresentasikan suatu tempat yang menjadi awal mula virus berpindah ke manusia. Adapun saat ini, penyakit sudah mewabah sehingga pembahasan difokuskan pada pola penyebaran virus melalui interaksi antar sesama manusia. Selain itu, manusia terpapar yang masih dalam masa inkubasi, diasumsikan dapat menularkan virus secara tidak sadar jika berinteraksi dengan manusia rentan, dimana asumsi ini juga belum dipertimbangkan pada model sebelumnya. Hal ini perlu dipertimbangkan karena diduga penyebaran kasus banyak terjadi melalui individu terpapar karena tidak adanya 


\section{R. Resmawan, et.al}

gejala apapun yang terdeteksi. Lebih lanjut, modifikasi dilakukan dengan menambahkan parameter yang mewakili kasus kematian yang disebabkan karena virus, melihat realita banyaknya kasus kematian karena COVID-19. Kasus kematian diasumsikan terjadi pada kelompok individu terinfeksi yang disertai gejala klinis.

Pada bagian analisis, kami fokus membahas tentang eksistensi titik kesetimbangan beserta kestabilannya. Pembahasan ini melanjutkan kajian kami sebelumnya terkait analisis sensitifitas yang menunjukkan bahwa parameter intervensi berupa karantina memiliki indeks sensitifitas yang tinggi pada transmisi COVID-19 [19]. Pada bagian akhir diberikan simulasi untuk menunjukkan secara visual, dinamika populasi dan kontribusi intervensi karantina dalam menekan laju transmisi COVID-19.

\section{Metode}

Metode yang digunakan dalam penelitian adalah studi literatur yang bertujuan untuk membangun model matematika yang merepresentasikan dinamika populasi pada proses transmisi COVID-19. Model yang dibahas pada penelitian ini adalah model matematika penyebaran COVID-19 tipe SEAQIR. Model tersebut dikontruksi berdasarkan asumsi yang sebagian telah dipaparkan dibagian awal artikel. Populasi manusia pada model ini terbagi atas enam kelas yaitu, manusia rentan $(S)$, manusia terpapar dalam masa inkubasi $(E)$, manusia terinfeksi tanpa gejala klinis $(A)$, manusia yang dikarantina $(Q)$, manusia terinfeksi disertai gejala klinis $(I)$, dan manusia yang pulih dari COVID-19 $(R)$.

Jumlah individu pada setiap kelas populasi dalam rentang waktu $t$ adalah $S(t), E(t)$, $A(t), Q(t), I(t), R(t)$. Adapun total inidividu pada populasi manusia dinotasikan dengan $N$ serta memenuhi $S(t)+E(t)+A(t)+Q(t)+I(t)+R(t)=N$. Beberapa pertimbangan atau batasan kami dalam merumuskan model matematika penyebaran COVID-19 kami rincikan sebagai berikut:

1. Laju rekrutmen kelahiran hanya ditujukan pada populasi $S$, dimana setiap individu yang baru lahir akan dimasukkan kedalam kelas manusia rentan.

2. Tingkat kematian terdiri atas tingkat kematian alami yang ditujukan kepada seluruh kelas populasi dan tingkat kematian disebabkan oleh COVID-19 yang hanya ditujukan pada populasi $I$.

3. Penularan COVID-19 terjadi ketika adanya kontak antara individu pada populasi $S$ dengan individu pada populasi $E$, individu pada populasi $A$, atau individu pada populasi $Q$.

4. Sebagian dari individu pada populasi $E$ akan melewati masa inkubasi dan masuk kedalam populasi $A$ atau populasi $I$.

5. Individu yang dikarantina $(Q)$ adalah individu yang berasal dari populasi $E$. Dengan kata lain proses karantina hanya diberlakukan pada populasi manusia terpapar.

6. Sebagian dari individu yang dikarantina dapat melewati masa inkubasi dan berpindah ke populasi $I$.

7. Sebagian dari individu pada populasi $A, Q$, dan $I$ akan mengalami pemulihan dan berpindah ke populasi $R$.

8. Individu yang telah dinyatakan pulih dari COVID-19 tidak akan kembali rentan.

Sesuai dengan pemaparan di atas, dibentuk diagram kompartemen pola penyebaran COVID-19 yang dapat dilihat pada Gambar 1. 


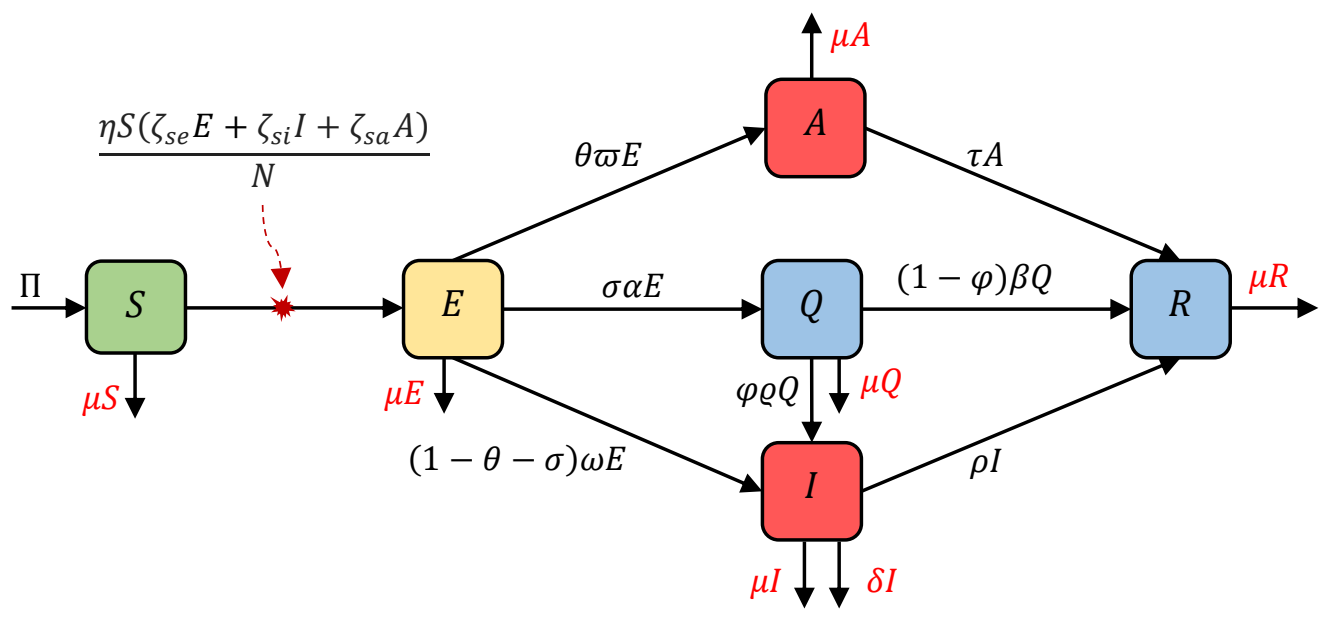

Gambar 1. Diagram kompartemen transmisi COVID-19

\section{Hasil dan Pembahasan}

\subsection{Model Matematika}

Diagram kompartemen pada Gambar 1 menjelaskan proses transmisi COVID-19 pada populasi manusia:

1. Laju rekrutmen kelahiran dan tingkat kematian alami manusia masing-masing diberikan oleh parameter $\Pi$ dan $\mu$. Manusia rentan $(S)$ akan terinfeksi melalui kontak yang cukup dengan individu rentan $(E)$, individu terinfeksi dengan gejala klinis $(I)$ maupun dengan individu terinfeksi tanpa gejala klinis $(A)$, masing-masing sebesar $\eta \zeta_{s e} S E, \eta \zeta_{s i} S I$, dan $\eta \zeta_{s a} S A$ dimana $\eta$ adalah peluang infeksi saat terjadi kontak antar individu.

2. Parameter $\zeta_{s e}, \zeta_{s i}$, dan $\zeta_{s a}$ masing-masing menyatakan laju kontak antara individu rentan $(S)$ kelompok individu $E, I$, dan $A$.

3. Parameter $\theta$ dan $\sigma$, masing-masing adalah proporsi individu yang terinfeksi tanpa gejala klinis proporsi individu terpapar yang dikarantina, sementara parameter $\alpha$ menyatakan laju perpindahan individu terpapar ke individu yang dikarantina.

4. Parameter $\omega$ dan $\varpi$ masing-masing merepresentasikan tingkat transmisi setelah menyelesaikan masa inkubasi dan berpindah ke kelas $I$ dan $A$.

5. Individu yang dikarantina dapat berpindah ke kelas individu terinfeksi yang disertai gejala klinis dengan laju $\varrho$, dengan proporsi individu sebesar $\varphi$.

6. Paramater $\tau, \beta, \rho$ masing-masing menyatakan tingkat pemulihan individu terinfeksi tanpa gejala klinis, individu dikarantina, dan individu terinfeksi disertai gejala klinis dan berpindah ke kelas individu yang telah pulih.

7. Selanjutnya, tingkat kematian yang disebabkan oleh virus COVID-19 pada kelas $I$ direpresentasikan dengan $\delta$.

Berdasarkan ilustrasi tersebut, dapat dirumuskan model matematika dalam bentuk system persamaan diferensial sebagai berikut: 
$\frac{d S}{d t}=\Pi-\frac{\eta S\left(\zeta_{s e} E+\zeta_{s i} I+\zeta_{s a} A\right)}{N}-\mu S$

$\frac{d E}{d t}=\frac{\eta S\left(\zeta_{s e} E+\zeta_{s i} I+\zeta_{s a} A\right)}{N}-(\theta \varpi+\sigma \alpha+\mu+\omega-\theta \omega-\sigma \omega) E$

$\frac{d A}{d t}=\theta \varpi E-(\tau+\mu) A$

$\frac{d Q}{d t}=\sigma \alpha E-(\varphi \varrho+\beta-\beta \varphi+\mu) Q$

$\frac{d I}{d t}=(1-\theta-\sigma) \omega E+\varphi \varrho Q-(\rho+\mu+\delta) I$

$\frac{d R}{d t}=\tau A+(1-\varphi) \beta Q+\rho I-\mu R$

dengan kondisi awal:

$S(0)=S_{0} \geq 0, \quad E(0)=E_{0} \geq 0, A(0)=A_{0} \geq 0$,

$Q(0)=Q_{0} \geq 0, \quad I(0)=I_{0} \geq 0, \quad R(0)=R_{0} \geq 0$.

Penjumlahan seluruh persamaan pada sistem (1) akan menghasilkan persamaan dinamika total populasi, yaitu

$$
\frac{d N}{d t}=\Pi-\mu N-\delta I
$$

Adapun bidang solusi pada sistem (1) memenuhi kondisi berikut:

$$
\Omega=\left\{(S(t), E(t), A(t), Q(t), I(t), R(t)) \in R_{+}^{6}: N(t) \leq \frac{\Pi}{\mu}\right\} .
$$

\subsection{Titik Kesetimbangan dan Kestabilannya}

Titik kesetimbangan adalah keadaan pada sistem persamaan (1) yang memenuhi kondisi

$$
\frac{d S}{d t}=\frac{d E}{d t}=\frac{d A}{d t}=\frac{d Q}{d t}=\frac{d I}{d t}=\frac{d R}{d t}=0
$$

Berdasarkan persamaan (2) diperoleh dua titik kesetimbangan dari sistem (1) yaitu; titik kesetimbangan bebas penyakit

$$
E_{0}=\left(S_{0}, 0,0,0,0,0\right)=\left(\frac{\Pi}{\mu}, 0,0,0,0,0\right)
$$

dan titik kesetimbangan endemik

dengan

$$
E_{1}=\left(S^{*}, E^{*}, A^{*}, Q^{*}, I^{*}, R^{*}\right)
$$




$$
\begin{array}{ll}
S^{*}=\frac{\Pi}{\kappa_{1}+\kappa_{2} E^{*}+\mu} & Q^{*}=\frac{\sigma \alpha E^{*}}{\varphi \varrho+\beta-\beta \varphi+\mu} \\
E^{*}=-\frac{\kappa_{1}}{\kappa_{2} S^{*}-(\theta \varpi+\sigma \alpha+\mu+\omega-\theta \omega-\sigma \omega)} & I^{*}=\frac{(1-\theta-\sigma) \omega E^{*}+\varphi \varrho Q^{*}}{\rho+\mu+\delta} \\
A^{*}=\frac{\theta \varpi E^{*}}{(\tau+\mu)} & R^{*}=\frac{\tau A^{*}+(1-\varphi) \beta Q^{*}+\rho I^{*}}{\mu}
\end{array}
$$

dimana

$$
\begin{gathered}
\kappa_{1}=\frac{\eta\left(\zeta_{s i} I^{*}+\zeta_{s a} A^{*}\right)}{S^{*}+E^{*}+A^{*}+Q^{*}+I^{*}+R^{*}} \\
\kappa_{2}=\frac{\eta \zeta_{s e}}{S^{*}+E^{*}+A^{*}+Q^{*}+I^{*}+R^{*}}
\end{gathered}
$$

Titik kesetimbangan $E_{0}$ dan $E_{1}$ selalu terdifinisi secara biologis, yaitu $E_{0,1} \in R_{+}^{6}$, karena semua parameter positif.

\subsection{Bilangan Reproduksi Dasar}

Bilangan reproduksi $\left(R_{0}\right)$ didefinisikan sebagai nilai harapan banyaknya infeksi yang terjadi tiap satuan waktu. Pada makalah ini, $R_{0}$ digunakan sebagai nilai ambang batas untuk melihat kemungkinan terjadinya wabah COVID-19. Bilangan reproduksi dasar $R_{0}$ diperoleh dari nilai eigen positif terbesar pada matriks next generation $K=F V^{-1}$ atau secara matematis dinyatakan sebagai $\rho\left(F V^{-1}\right)$ [20]. Adapun matriks next generation $K$ diperoleh dari sistem persamaan (1) dan persamaan (3) yang memuat kelas populasi terpapar, kelas populasi terinfeksi tanpa gejala klinis, dan kelas populasi terinfeksi disertai gejala klinis, yaitu

$$
K=F V^{-1}
$$

dengan

$F=\left[\begin{array}{cccc}\eta \zeta_{s e} & \eta \zeta_{s a} & 0 & \eta \zeta_{s i} \\ 0 & 0 & 0 & 0 \\ 0 & 0 & 0 & 0 \\ 0 & 0 & 0 & 0\end{array}\right]$ dan

$V=\left[\begin{array}{cccc}\theta \varpi+\sigma \alpha+\mu+\omega-\theta \omega-\sigma \omega & 0 & 0 & 0 \\ -\theta \varpi & \tau+\mu & 0 & 0 \\ -\sigma \alpha & 0 & \varphi \varrho+\beta-\beta \varphi+\mu & 0 \\ -(1-\theta-\sigma) \omega & 0 & -\varphi \varrho & \rho+\mu+\delta\end{array}\right]$

$R_{0}$ diperoleh dari nilai eigen positif tersebesar dari matriks $K$ [19] dan dapat ditulis:

$$
\begin{aligned}
& R_{0}=\frac{\eta \zeta_{s e}(\tau+\mu)+\eta \zeta_{s a} \theta \varpi}{(\tau+\mu)(\mu+\omega+\theta \varpi+\alpha \sigma-\theta \omega-\sigma \omega)} \\
& +\frac{\eta \zeta_{s i} \varphi \varrho \alpha \sigma+\eta \zeta_{s i}(\omega-\sigma \omega-\theta \omega)(\mu+\beta-\beta \varphi+\varphi \varrho)}{(\mu+\delta+\rho)(\mu+\beta-\beta \varphi+\varphi \varrho)(\mu+\omega+\theta \varpi+\alpha \sigma-\theta \omega-\sigma \omega)} .
\end{aligned}
$$

Dalam bentuk sederhana, $R_{0}$ dapat dinyatakan sebagai:

$$
R_{0}=R_{1}+R_{2}
$$

dengan 


$$
\begin{aligned}
& R_{1}=\frac{\eta \zeta_{s e}(\tau+\mu)+\eta \zeta_{s a} \theta \varpi}{(\tau+\mu)(\mu+\omega+\theta \varpi+\alpha \sigma-\theta \omega-\sigma \omega)} \\
& R_{2}=\frac{\eta \zeta_{s i} \varphi \varrho \alpha \sigma+\eta \zeta_{s i}(\omega-\sigma \omega-\theta \omega)(\mu+\beta-\beta \varphi+\varphi \varrho)}{(\mu+\delta+\rho)(\mu+\beta-\beta \varphi+\varphi \varrho)(\mu+\omega+\theta \varpi+\alpha \sigma-\theta \omega-\sigma \omega)}
\end{aligned}
$$

\subsection{Analisis Stabilitas Titik Kesetimbangan}

Teorema 1. Titik kesetimbangan bebas penyakit $\left(E_{0}\right)$ dari sistem pada persamaan (6) stabil asimtotik lokal pada saat $R_{0}<1$ dan tidak stabil pada saat $R_{0}>1$.

Bukti. Matriks jacobian dari model pada persamaan (6) didefiniskan sebagai,

$$
\boldsymbol{J}=\left[\begin{array}{cccccc}
J_{11} & J_{12} & J_{13} & 0 & J_{15} & 0 \\
J_{21} & J_{22} & J_{23} & 0 & J_{25} & 0 \\
0 & J_{32} & J_{33} & 0 & 0 & 0 \\
0 & J_{42} & 0 & J_{44} & 0 & 0 \\
0 & J_{52} & 0 & J_{54} & J_{55} & 0 \\
0 & 0 & J_{63} & J_{64} & J_{65} & J_{66}
\end{array}\right]
$$

dengan

$$
\begin{aligned}
& J_{11}=\frac{\eta\left(\zeta_{s e} E+\zeta_{s i} I+\zeta_{s a} A\right)}{N}-\mu \quad J_{12}=\frac{\eta \zeta_{s e} S}{N} \quad J_{13}=\frac{\eta \zeta_{s a} S}{N} \quad J_{15}=\frac{\eta \zeta_{s i} S}{N} \\
& J_{21}=\frac{\eta\left(\zeta_{s e} E+\zeta_{s i} I+\zeta_{s a} A\right)}{N} \quad J_{22}=\frac{\eta \zeta_{s e} S}{N}-(\theta \varpi+\sigma \alpha+\mu+\omega-\theta \omega-\sigma \omega) \\
& J_{23}=\frac{\eta \zeta_{s a} S}{N} \quad J_{25}=\frac{\eta \zeta_{s i} S}{N} \quad J_{32}=\theta \varpi \quad J_{33}=-(\tau+\mu) \quad J_{42}=\sigma \alpha \\
& J_{44}=-(\varphi \varrho+\beta-\beta \varphi+\mu) \quad J_{52}=(1-\theta-\sigma) \omega \quad J_{54}=\varphi \varrho \\
& J_{55}=-(\rho+\mu+\delta) \quad J_{63}=\tau \quad J_{64}=(1-\varphi) \beta \quad J_{65}=\rho \quad J_{66}=-\mu
\end{aligned}
$$

Selanjutnya dilakukan evaluasi disekitar titik kesetimbangan bebas penyakit pada persamaan (3), menghasilkan matriks Jacobian untuk $E_{0}$ yang didefinisikan,

$$
\boldsymbol{J}\left(E_{0}\right)=\left[\begin{array}{cccccc}
J_{11} & J_{12} & J_{13} & 0 & J_{15} & 0 \\
0 & J_{22} & J_{23} & 0 & J_{25} & 0 \\
0 & J_{32} & J_{33} & 0 & 0 & 0 \\
0 & J_{42} & 0 & J_{44} & 0 & 0 \\
0 & J_{52} & 0 & J_{54} & J_{55} & 0 \\
0 & 0 & J_{63} & J_{64} & J_{65} & J_{66}
\end{array}\right]
$$

dengan

$$
\begin{aligned}
& J_{11}=-\mu \quad J_{12}=\eta \zeta_{s e} \quad J_{13}=\eta \zeta_{s a} \quad J_{15}=\eta \zeta_{s i} \\
& J_{22}=\eta \zeta_{s e}-(\mu+\omega+\theta \varpi+\sigma \alpha-\theta \omega-\sigma \omega) \quad J_{23}=\eta \zeta_{s a} \quad J_{25}=\eta \zeta_{s i} \\
& J_{32}=\theta \varpi \quad J_{33}=-(\tau+\mu) \quad J_{42}=\sigma \alpha \quad J_{44}=-(\varphi \varrho+\beta-\beta \varphi+\mu) \\
& J_{52}=(1-\theta-\sigma) \omega \quad J_{54}=\varphi \varrho \quad J_{55}=-(\rho+\mu+\delta) \\
& J_{63}=\tau \quad J_{64}=(1-\varphi) \beta \quad J_{65}=\rho \quad J_{66}=-\mu
\end{aligned}
$$


Dari matriks jacobian $J\left(E_{0}\right)$ pada persamaan (9), diperoleh persamaan karakteristik,

$$
\begin{aligned}
\left(\lambda-J_{11}\right)\left(\lambda-J_{66}\right) & \left(\lambda^{4}-\lambda^{3} J_{22}-\lambda^{3} J_{33}-\lambda^{3} J_{44}-\lambda^{3} J_{55}-\lambda^{2} J_{52}{ }^{2}+\lambda^{2} J_{22} J_{33}-\lambda^{2} J_{23} J_{32}\right. \\
& +\lambda^{2} J_{22} J_{44}+\lambda^{2} J_{22} J_{55}+\lambda^{2} J_{33} J_{44}+\lambda^{2} J_{33} J_{55}+\lambda^{2} J_{44} J_{55}+\lambda J_{33} J_{52}{ }^{2}+\lambda J_{52}{ }^{2} J_{44} \\
& -\lambda J_{22} J_{33} J_{44}+\lambda J_{23} J_{32} J_{44}-\lambda J_{22} J_{33} J_{55}+\lambda J_{23} J_{32} J_{55}-\lambda J_{22} J_{44} J_{55}-\lambda J_{42} J_{52} J_{54} \\
& \left.-\lambda J_{33} J_{44} J_{55}+J_{22} J_{33} J_{44} J_{55}-J_{33} J_{44} J_{52}{ }^{2}-J_{23} J_{32} J_{44} J_{55}+J_{33} J_{42} J_{52} J_{54}\right)=0 .
\end{aligned}
$$

Dari persamaan karakteristik sebelumnya diperoleh 6 nilai eigen, 2 diantaranya dapat dipastikan kenegatifannya yaitu

$\lambda_{1}=J_{11}=-\mu<0$

$\lambda_{3}=J_{66}=-\mu<0$

sementara 4 nilai eigen lainnya diperoleh dari persamaan polinomial orde empat, yaitu

dengan

$$
A_{0} \lambda^{4}+A_{1} \lambda^{3}+A_{2} \lambda^{2}+A_{3} \lambda+A_{4}=0
$$

$A_{0}=1$

$A_{1}=(\tau+\mu)+(\varphi \varrho+\beta-\beta \varphi+\mu)+(\rho+\mu+\delta)-\left(R_{1}-1\right)$

$A_{2}=(\tau+\mu)(\varphi \varrho+\beta-\beta \varphi+\mu+\rho+\mu+\delta)+(\rho+\mu+\delta)(\varphi \varrho+\beta-\beta \varphi+\mu)-\eta \zeta_{s a} \theta \varpi$

$-(1-\theta-\sigma)^{2} \omega^{2}-(\tau+\mu+\varphi \varrho+\beta-\beta \varphi+\mu+\rho+\mu+\delta)\left(R_{1}-1\right)$

$A_{3}=(\tau+\mu)(\rho+\mu+\delta)(\varphi \varrho+\beta-\beta \varphi+\mu)$

$-\left(R_{1}-1\right)((\tau+\mu)(\mu+\beta-\beta \varphi+\varphi \varrho+\rho+\mu+\delta)$

$+(\rho+\mu+\delta)(\mu+\beta-\beta \varphi+\varphi \varrho))-\left(R_{2}-1\right)$

$A_{4}=-\left(R_{1}-1\right)(\rho+\mu+\delta)(\tau+\mu)(\varphi \varrho+\beta-\beta \varphi+\mu)-\left(R_{2}-1\right)$

Stabilitas sistem diidentifikasi dengan menggunakan kriteria Ruth-Hurwitz [21]. Kriteria Ruth-Hurwitz dapat dilakukan apabila koefisien polinom pada persamaan (10) bernilai positif.

Jika $R_{0}>1$, maka $A_{i}<0, i=1,2,3,4$ sehingga sistem tidak stabil. Jika $R_{0}<1$, maka $A_{i}>$ $0, i=0,1,2,3,4$. Selanjutnya, kriteria Ruth-Hurwitz untuk polinomial orde empat, yaitu $A_{i}>0, i=0,1,2,3, A_{1} A_{2}>A_{3}$, dan $A_{1} A_{2} A_{3}>A_{1} A_{4}+A_{3}^{2}$ dapat ditunjukkan dengan menggunakan koefisien persamaan (15). Dengan demikian, titik kesetimbangan bebas penyakit $\left(E_{0}\right)$ dari sistem persamaan (1) bersifat stabil asimtotik lokal pada saat $R_{0}<1$ dan tidak stabil pada saat $R_{0}>1$. $\square$

\subsection{Simulasi Numerik}

Nilai parameter model yang digunakan pada sistem persamaan (1), mempertimbangkan nilai parameter hasil fitting dari berbagai referensi terpercaya berdasarkan kasus real COVID-19 yang terlaporkan dan telah dipublikasikan. Nilai-nilai parameter yang digunakan pada simulasi, ditampilkan pada Tabel 1. Selanjutnya, nilai awal yang digunakan pada model adalah total populasi awal $N(0)=267.289 .750$ dengan $N(0)=$ $S(0)+E(0)+A(0)+I(0)+Q(0)+R(0)$. Adapun nilai awal variabel dipertimbangkan berdasarkan data kasus yang terjadi pada bulan april yaitu $I(0)=5.923, E(0)=5.684$, $A(0)=5.000, Q(0)=4.796, R(0)=0$, dan $S(0)=267.283 .391$. Dengan menggunakan nilai nilai parameter pada Tabel 1 , diperoleh estimasi bilangan reproduksi dasar diperkirakan sebesar $R_{0} \approx 2$. Hal ini berarti bahwa setiap individu terinfeksi berpotensi menularkan penyakit kepada minimal 2 individu baru. 
Tabel 1. Estimasi nilai parameter pada kasus COVID-19

\begin{tabular}{|c|c|c|c|}
\hline Variabel & Keterangan & Nilai & Sumber \\
\hline$\Pi$ & Laju rekrutmen kelahiran & 3.947.567 & Estimasi \\
\hline$\mu$ & Laju kematian alami & $3,57 \times 10^{-5}$ & Estimasi \\
\hline$\eta$ & Peluang transmisi saat terjadi kontak & 0,2 & Estimasi \\
\hline$\zeta_{s e}$ & $\begin{array}{l}\text { Laju kontak individu rentan dengan } \\
\text { individu terpapar }\end{array}$ & 0,09 & Estimasi \\
\hline$\zeta_{s a}$ & $\begin{array}{l}\text { Laju kontak individu rentan dengan } \\
\text { individu terinfeksi tanpa gejala klinis }\end{array}$ & 0,07 & Estimasi \\
\hline$\zeta_{s i}$ & $\begin{array}{l}\text { Laju kontak individu rentan dengan } \\
\text { individu terinfeksi disertai gejala klinis }\end{array}$ & 0,05 & [10] \\
\hline$\theta$ & $\begin{array}{l}\text { Proporsi individu yang terinfeksi tanpa gejala } \\
\text { klinis }\end{array}$ & 0,12 & Estimasi \\
\hline$\sigma$ & Proporsi individu terpapar yang dikarantina & 0,04 & Estimasi \\
\hline$\alpha$ & $\begin{array}{l}\text { Laju perpindahan individu terpapar ke } \\
\text { individu karantina }\end{array}$ & 0,13266 & [9] \\
\hline$\omega$ & $\begin{array}{l}\text { Laju transmisi setelah menyelesaikan masa } \\
\text { inkubasi dan berpindah ke kelas terinfeksi } \\
\text { desertai gejala klinis }\end{array}$ & 0,005 & [10] \\
\hline $\bar{\omega}$ & $\begin{array}{l}\text { Laju transmisi setelah menyelesaikan masa } \\
\text { inkubasi dan berpindah ke kelas terinfeksi } \\
\text { tanpa gejala klinis }\end{array}$ & 0,00048 & [10] \\
\hline$\varrho$ & $\begin{array}{l}\text { Laju perpindahan individu yang dikarantina } \\
\text { ke individu terinfeksi disertai gejala klinis }\end{array}$ & 0,1259 & [9] \\
\hline$\varphi$ & $\begin{array}{l}\text { Proporsi individu dikarantina yang terinfeksi } \\
\text { disertai gejala klinis }\end{array}$ & 0,05 & Estimasi \\
\hline$\tau$ & $\begin{array}{l}\text { Laju pemulihan individu yang terinfeksi } \\
\text { tanpa gejala klinis dan berpindah ke kelas } \mathrm{R}\end{array}$ & 0,854302 & [10] \\
\hline$\beta$ & $\begin{array}{l}\text { Laju pemulihan individu yang dikarantina } \\
\text { dan berpindah ke kelas } R\end{array}$ & 0,11624 & [9] \\
\hline$\rho$ & $\begin{array}{l}\text { Laju pemulihan individu yang terinfeksi } \\
\text { disertai gejala klinis dan berpindah ke kelas } \mathrm{R}\end{array}$ & 0,33029 & [9] \\
\hline$\delta$ & $\begin{array}{l}\text { Laju kematian yang disebabkan karena } \\
\text { COVID-19 pada kelas inidividu yang } \\
\text { terinfeksi disertai gejala klinis }\end{array}$ & $1,78 \times 10^{-5}$ & [9] \\
\hline
\end{tabular}

Hasil pengamatan kami untuk perkembangan kasus harian COVID-19 di Indonesia khususnya pada bulan april terus mengalami peningkatan. Penambahan kasus yang dilaporkan merupakan data dari spesimen yang telah dilakukan pengujian dan menunjukkan hasil positif COVID-19. Selanjutnya dilakukan perhitungan terhadap jumlah individu yang masih dalam tahap pengobatan dengan cara mengurangkan total kasus harian COVID-19 dengan total individu yang dinyatakan meninggal dan dinyatakan sembuh. Kami memperoleh hasil perhitungan dari jumlah individu dalam tahap pengobatan memiliki karakteristik yang sama dengan jumlah individu terpapar pada model SEAQIR. Gambar 2 menunjukkan bahwa jumlah individu yang dilaporkan masih dalam pengobatan khususnya dibulan april 2020 sempat mengalami penurunan hingga akhirnya terus mengalami peningkatan. Hal yang sama juga berlaku pada hasil perhitungan atau prediksi kami dengan menggunakan model SEAQIR. 
Analisis Dinamik Model Transmisi COVID-19 dengan Melibatkan Intervensi Karantina

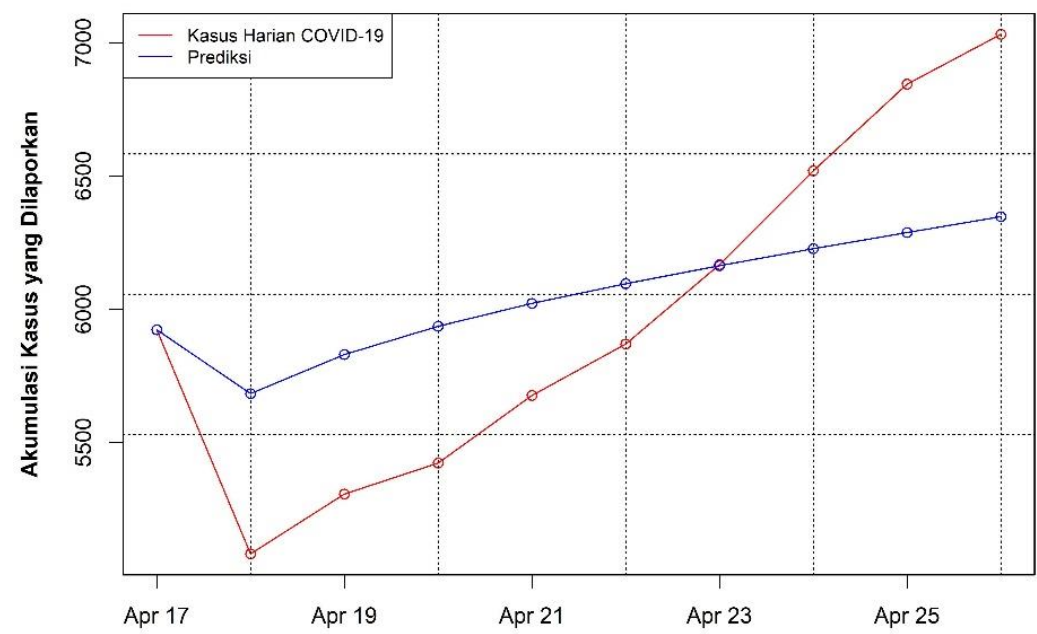

Gambar 2. Perbandingan data kasus harian COVID-19 di Indonesia dengan hasil prediksi menggunakan model SEAQIR
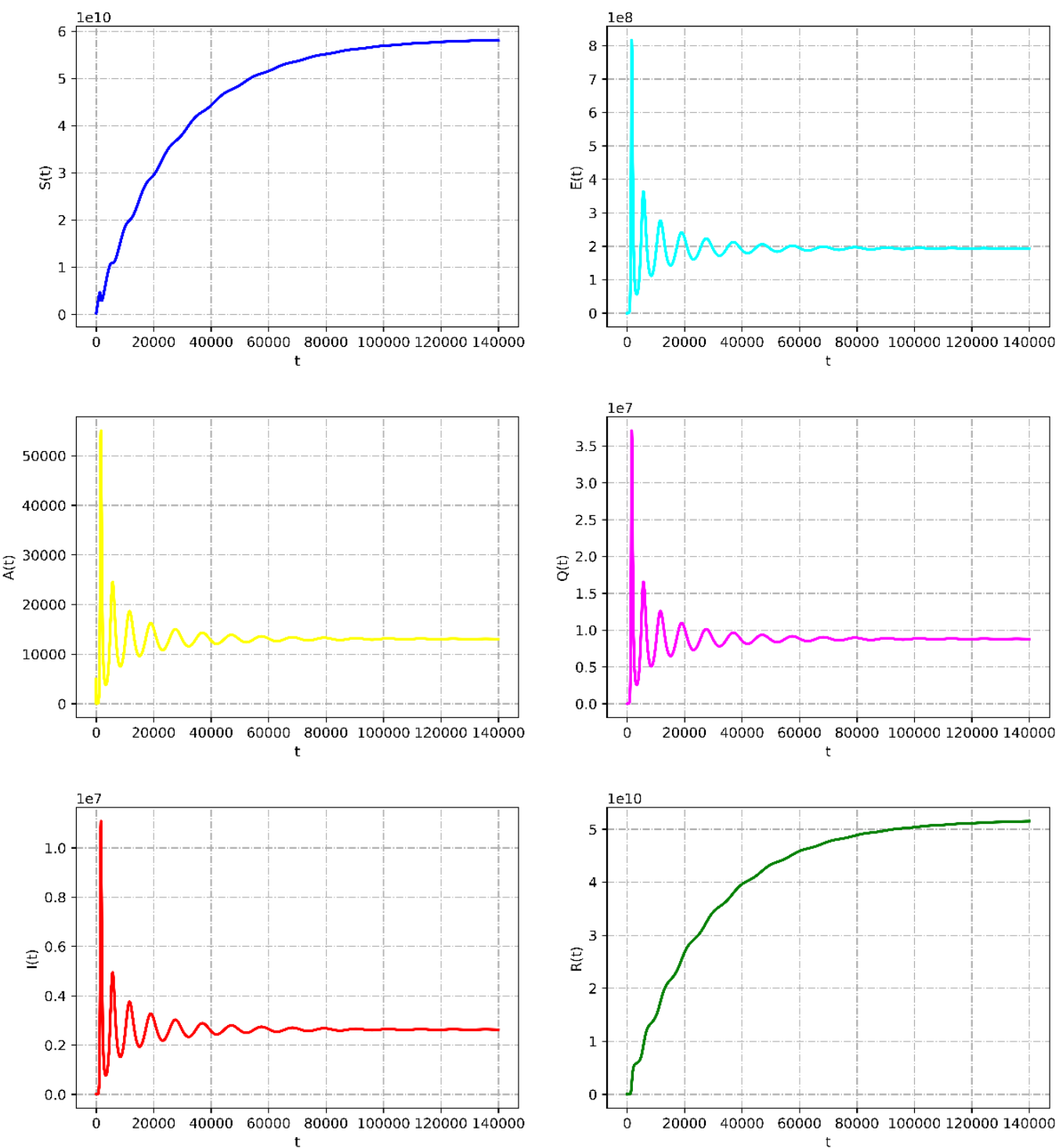

Gambar 3. Simulasi dinamika penyebaran COVID-19 
Selanjutnya kami melakukan simulasi lebih lanjut untuk melihat sifat kestabilan dari setiap kelas populasi terhadap dinamika penyebaran COVID-19. Berdasarkan Gambar 3 dapat dilihat bahwa populasi menuju titik kesetimbangan endemik atau stabil disekitar titik endemik. Populasi manusia yang rentan terhadap virus corona dan populasi manusia terpapar dalam masa inkubasi mengalami peningkatan pada awal waktu kemudian mengalami penurunan jumlah populasi hingga stabil pada kondisi $S \approx$ $5,85268 \times 10^{10}$ dan $E \approx 1,93565 \times 10^{8}$. Populasi manusia yang terinfeksi tanpa gejala klinis, manusia yang dikarantina dan manusia yang sembuh mengalami peningkatan jumlah populasi hingga stabil pada kondisi $A \approx 13.050,2, Q \approx 8,79704 \times 10^{6}$, dan $I \approx$ $2,62862 \times 10^{6}$. Populasi manusia yang sembuh pada awal waktu mengalami kestabilan pada kondisi $R \approx 5,1843 \times 10^{10}$.

Kami melakukan simulasi terhadap perubahan nilai $\alpha$, untuk mengetahui pengaruh penerapan karantina terhadap penyebaran COVID-19. Pada Gambar 4 terlihat penurunan nilai $\alpha$ sebesar $10 \%$ dan $20 \%$ memberikan pengaruh yang siginifikan terhadap kenaikan jumlah individu pada kelas populasi manusia terpapar, manusia terinfeksi tanpa gejala klinis, dan manusia terinfeksi dengan gejala klinis. Adapun jumlah individu pada kelas populasi manusia yang dikarantina mengalami penurunan terhadap perubahan nilai $\alpha$ tersebut. Selain itu, penurunan nilai $\alpha$ dapat mempercepat terjadinya penyebaran COVID-19.
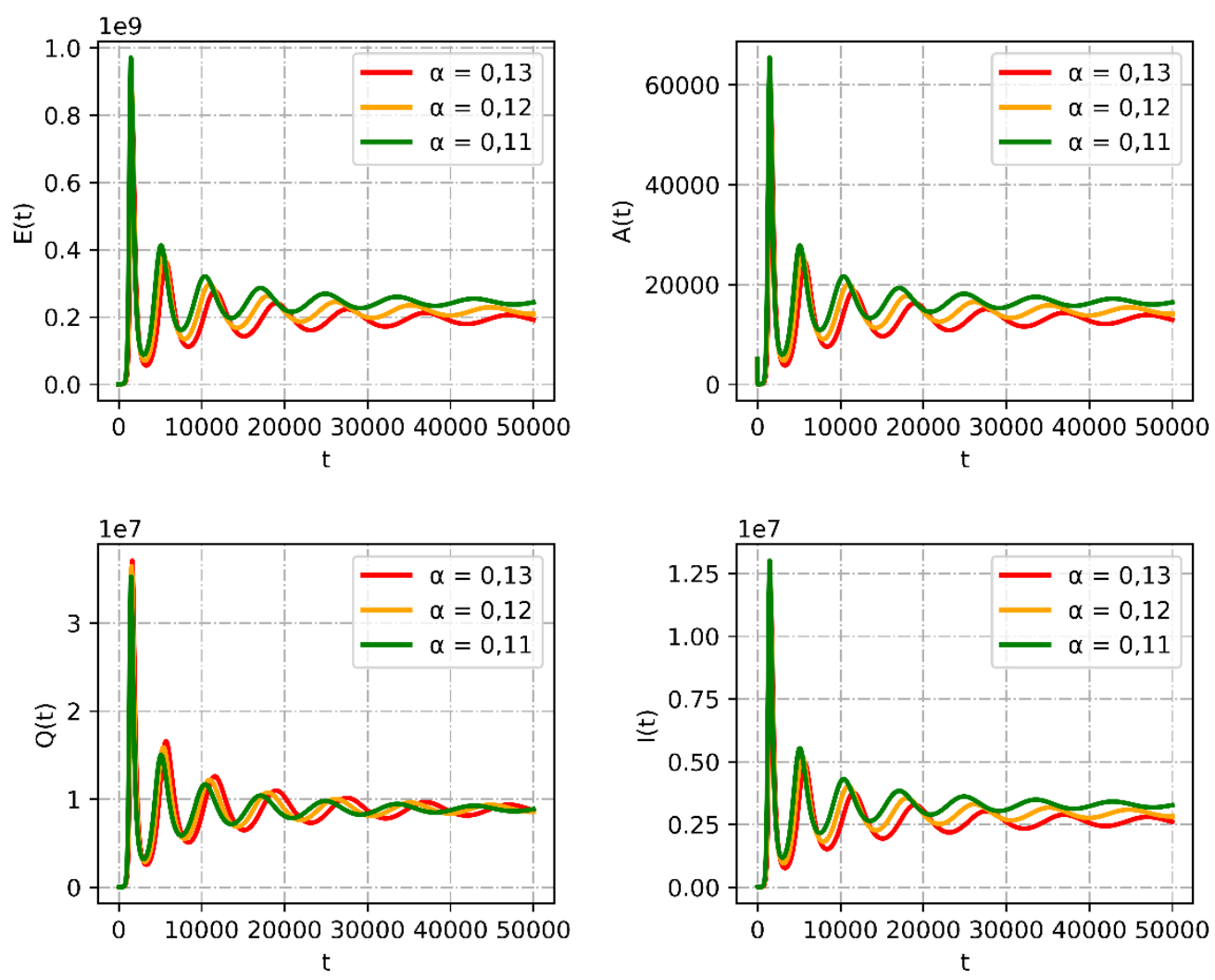

Gambar 4. Pengaruh laju perpindahan individu terpapar ke individu karantina terhadap penyebaran COVID-19

Adapun hasil pengamatan perubahan nilai $\alpha$ terhadap nilai $R_{0}$ dapat dilihat pada Gambar 5. Peningkatan nilai $\alpha$ mengakibatkan nilai $R_{0}$ semakin menurun hingga mencapai kondisi tidak terjadi wabah pada sistem. Sesuai dengan Teorema 1, kondisi 
tidak terjadi wabah merupakan kondisi yang akan tercapai jika $R_{0}<1$. Hasil perhitungan kami dengan meningkatkan nilai $\alpha$ lebih dari tiga kali lipat dari nilai semula serta nilai parameter lainnya dianggap konstan akan mengakibatkan sistem mencapai kondisi $R_{0}<1$.

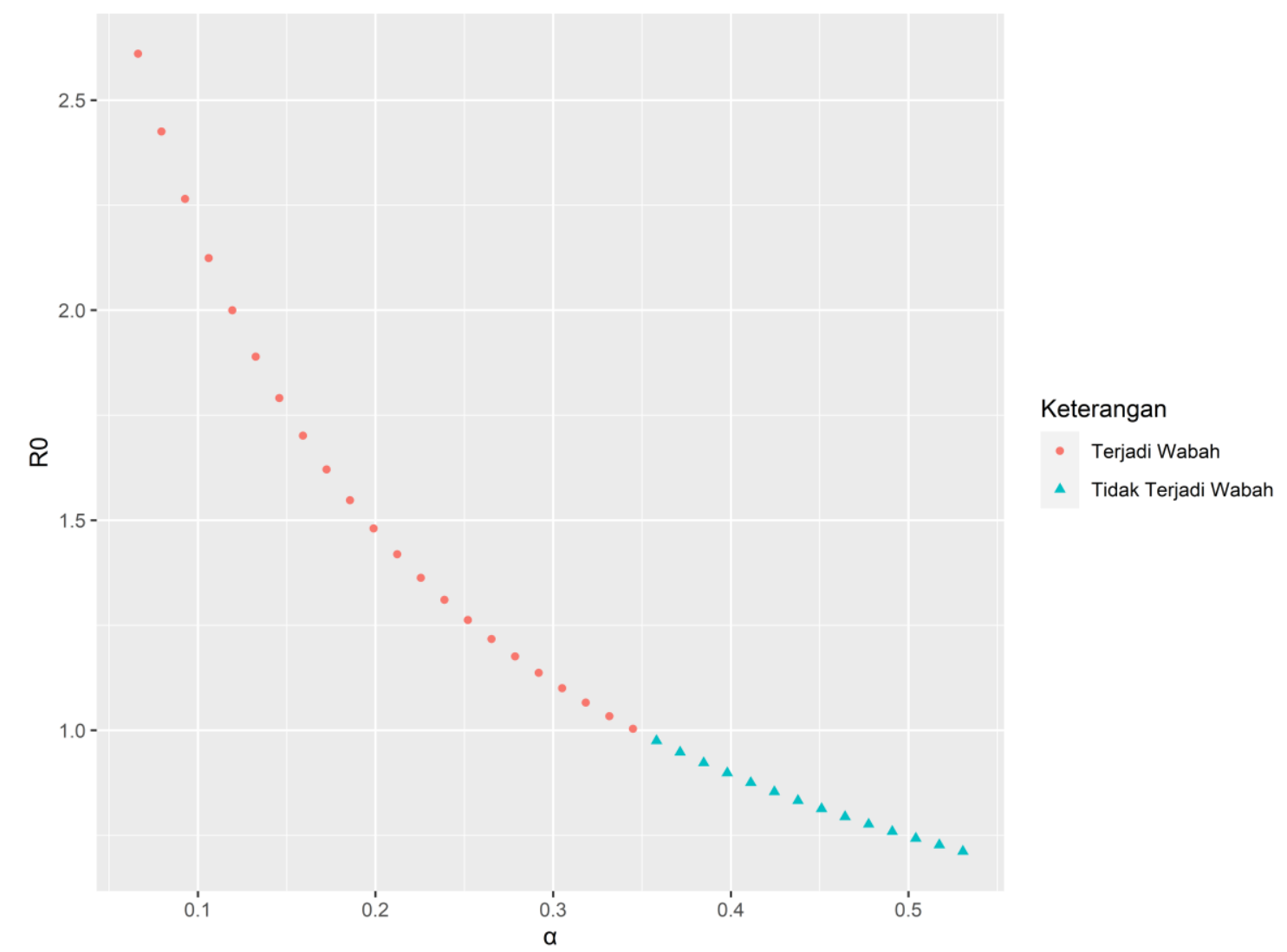

Gambar 5. Pengaruh laju perpindahan individu terpapar ke individu karantina terhadap bilangan reproduksi dasar

Simulasi ini menunjukkan bahwa peningkatan intervensi berupa karantina mampu menekan bilangan reproduksi dasar, yang berarti dapat memperlambat terjadinya penularan COVID-19 serta mencegah terjadinya wabah. Oleh karena itu, salah satu alternatif yang dapat dilakukan untuk menekan penyebaran COVID-19 adalah dengan meningkatkan intervensi karantina pada manusia yang terdeteksi terpapar virus. Hal ini dapat dimaksimalkan dengan melakukan tes massal untuk memperbanyak identifikasi manusia yang telah terpapar COVID-19.

\section{Kesimpulan}

Modifikasi model dengan strategi karantina pada kelas manusia terpapar $E$ serta pertimbangan tiga kelas penyebab infeksi $E, A$ dan $I$ menghasilkan model matematika penyebaran COVID-19 tipe SEAQIR. Titik kesetimbangan dari model SEAQIR terdiri atas titik kesetimbangan bebas penyakit dan titik kesetimbangan endemik. Analisis kestabilan sistem menunjukkan bahwa titik kesetimbangan bebas penyakit bersifat stabil asimtotik lokal pada saat $R_{0}<1$ dan tidak stabil pada saat $R_{0}>1$. Simulasi menunjukkan bahwa sistem akan stabil disekitar titik kesetimbangan endemik, yang berarti bahwa penyakit akan terus mewabah jika tidak ada intervensi yang secara serius 
dapat menekan angka $R_{0}$. Adapun peningkatan nilai parameter intervensi karantina berkontribusi menurunkan $R_{0}$. Oleh karena itu, salah satu alternatif yang dapat dilakukan untuk menekan penyebaran COVID-19 adalah dengan meningkatkan intervensi karantina pada manusia yang terdeteksi terpapar virus. Hal ini dapat dimaksimalkan dengan melakukan tes massal untuk memperbanyak identifikasi manusia yang telah terpapar COVID-19.

\section{Ucapan Terima Kasih}

Ucapan terimakasih diberikan kepada reviewer atas komentar dan saran yang membangun demi meningkatkan kualitas artikel ini.

\section{Referensi}

[1] N. Al-Rousan and H. Al-Najjar, "The correlation between the spread of COVID19 infections and weather variables in 30 Chinese provinces and the impact of Chinese government mitigation plans," Eur Rev Med Pharmacol Sci, vol. 24, no. 8, pp. 4565-4571, 2020.

[2] C. Huang et al., "Clinical features of patients infected with 2019 novel coronavirus in Wuhan, China," Lancet, vol. 395, no. 10223, pp. 497-506, Feb. 2020.

[3] N. Chen et al., "Epidemiological and clinical characteristics of 99 cases of 2019 novel coronavirus pneumonia in Wuhan, China: a descriptive study," Lancet, vol. 395, no. 10223, pp. 507-513, Feb. 2020.

[4] R. Lu et al., "Genomic characterisation and epidemiology of 2019 novel coronavirus: implications for virus origins and receptor binding," Lancet, vol. 395, no. 10224, pp. 565-574, Feb. 2020.

[5] T. Li, "Diagnosis and clinical management of severe acute respiratory syndrome Coronavirus 2 (SARS-CoV-2) infection: an operational recommendation of Peking Union Medical College Hospital (V2.0)," Emerg. Microbes Infect., vol. 9, no. 1, pp. 582-585, Jan. 2020.

[6] M. Li et al., "Identifying novel factors associated with COVID-19 transmission and fatality using the machine learning approach," Sci. Total Environ., p. 142810, Oct. 2020.

[7] B. Tang et al., "Estimation of the Transmission Risk of the 2019-nCoV and Its Implication for Public Health Interventions," J. Clin. Med., vol. 9, no. 2, p. 462, Feb. 2020.

[8] B. Tang, N. L. Bragazzi, Q. Li, S. Tang, Y. Xiao, and J. Wu, “An updated estimation of the risk of transmission of the novel coronavirus (2019-nCov)," Infect. Dis. Model., vol. 5, pp. 248-255, 2020.

[9] B. Tang et al., "The effectiveness of quarantine and isolation determine the trend of the COVID-19 epidemics in the final phase of the current outbreak in China," Int. J. Infect. Dis., vol. 95, pp. 288-293, Jun. 2020.

[10] M. A. Khan and A. Atangana, "Modeling the dynamics of novel coronavirus (2019-nCov) with fractional derivative," Alexandria Eng. J., vol. 59, no. 4, pp. 23792389, Aug. 2020. 
[11] M. A. Khan and A. Atangana, "Modeling the dynamics of novel coronavirus (2019-nCov) with fractional derivative," Alexandria Eng. J., 2020.

[12] T.-M. Chen, J. Rui, Q.-P. Wang, Z.-Y. Zhao, J.-A. Cui, and L. Yin, "A mathematical model for simulating the phase-based transmissibility of a novel coronavirus," Infect. Dis. Poverty, vol. 9, no. 1, p. 24, Dec. 2020.

[13] T. Kuniya, "Prediction of the Epidemic Peak of Coronavirus Disease in Japan, 2020," J. Clin. Med., vol. 9, no. 3, p. 789, Mar. 2020.

[14] H. Sun, Y. Qiu, H. Yan, Y. Huang, Y. Zhu, and S. X. Chen, "Tracking and Predicting COVID-19 Epidemic in China Mainland," J. Data Sci., vol. 18, no. 3, pp. 455-472, 2020.

[15] C. T. Deressa and G. F. Duressa, "Modeling and optimal control analysis of transmission dynamics of COVID-19: The case of Ethiopia," Alexandria Eng. J., vol. 60, no. 1, pp. 719-732, Feb. 2021.

[16] D. Kada, A. Kouidere, O. Balatif, M. Rachik, and E. H. Labriji, "Mathematical modeling of the spread of COVID-19 among different age groups in Morocco: Optimal control approach for intervention strategies," Chaos, Solitons \& Fractals, vol. 141, p. 110437, Dec. 2020.

[17] B. Tang et al., "Estimation of the Transmission Risk of the 2019-nCoV and Its Implication for Public Health Interventions," J. Clin. Med., vol. 9, no. 2, p. 462, 2020.

[18] P. Li et al., "Transmission of COVID-19 in the terminal stages of the incubation period: A familial cluster," Int. J. Infect. Dis., vol. 96, no. February, pp. 452-453, 2020.

[19] R. Resmawan and L. Yahya, "Sensitivity Analysis of Mathematical Model of Coronavirus Disease (COVID-19) Transmission," CAUCHY, vol. 6, no. 2, pp. 9199, May 2020.

[20] P. van den Driessche and J. Watmough, "Reproduction numbers and subthreshold endemic equilibria for compartmental models of disease transmission," Math. Biosci., vol. 180, no. 1-2, pp. 29-48, Nov. 2002.

[21] S. Fisher, Complex Variables. California (US): Wadsworth \& Brooks, 1990.

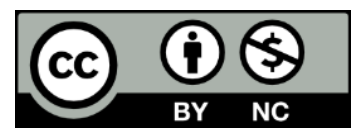

This article is an open access article distributed under the terms and conditions of the Creative Commons Attribution-NonCommercial 4.0 International License. Editorial of JoM: Department of Mathematics, Universitas Negeri Gorontalo, Jln. Prof. Dr. Ing. B.J. Habibie, Moutong, Tilongkabila, Kabupaten Bone Bolango, Provinsi Gorontalo 96119, Indonesia. 